\title{
The International Criminal Court and Africa: Exemplary Justice
}

Edwin Bikundo

\begin{abstract}
This is a theoretical and empirical investigation into the causal link (if any) between international criminal trials and preventing violence through exemplary prosecutions. Specifically how do representative trials of persons accused of having the greatest responsibility for the most serious crimes of concern to the international community as a whole, supposedly bind recurrent violence? The argument pursued is that by using an accused as an example, a court engages in an indirect and uncertain substitution of personal rights for social harmony and order.

These prosecutions combine a peculiar rhetoric, logic and aesthetic all which substitute the responsibilities for a society in general to a particular individual in order to redeem that society by transferring its communal responsibility onto the individual punished as a form of atonement or expiation. International and domestic trials as well as truth and reconciliation commissions are part of a suite of options addressing communal mass violence that can work in tandem. However, because those convicted do not have a monopoly on criminality nor do those merely reconciled have a monopoly on virtue, exemplification through punishment only targets a few on behalf of the many. Indeed such a redemptively sacrificial economy distinguishes legal justice from mere vengeance.
\end{abstract}

Keywords Africa $\bullet$ Criminal Trials• International Criminal Court •International Criminal Law • Punishment $\bullet$ Sacrifice

E. Bikundo, School of Criminology and Criminal Justice

176 Messines Ridge Road

Mt Gravatt Campus

Griffith University Qld 4111

AUSTRALIA

Tel+61737351158; facsimile+61737355608; email e.bikundo@griffith.edu.au. 


\section{Individual Criminal Responsibility for Mass Political Violence}

There is always it seems something new from Africa in the International Criminal Court's (ICC) case docket. As of this writing that court has five situations and cases from Uganda, Sudan, the Democratic Republic of Congo, the Central African Republic and Kenya (ICC 2011c). The United Nations Security Council recently referred Libya by unanimous resolution to the court (UN 2011) and the ICC prosecutor has opened a preliminary examination into the Ivory Coast (ICC 2011c). All these in a court that was set up it is said, to punish those most responsible for 'the most serious crimes of concern to the international community as a whole' that 'deeply shock the conscience of humanity' (Rome Statute of the International Criminal Court 1998: Preamble and Article 1 afterwards the Rome Statute). Faced with this rhetorical claim, surely the proper scholarly attitude then can only be an inquisitively open minded scepticism towards Africans having a near monopoly of these crimes and prescribing select criminal trials as being the panacea. This paper casts a critical eye at two apparently unrelated fields of inquiry both addressing an ethical gap between the theory and the practice of international criminal justice. The first regards a certain ethical ambivalence about whether a criminal trial relying on individual criminal responsibility can prevent the recurrence of mass violence. The second highlights the ethical ambiguity of how a universal court designed and intended to prosecute those most responsible for the worst crimes known to humanity only has cases from a single continent whether by coincidence or not. The problematic link between those otherwise unrelated questions in the context of international criminal justice is the continent and peoples of Africa. The central question structuring this piece is how do representative trials of persons accused of having the greatest responsibility for the most serious crimes of concern to the international community as a whole supposedly bind recurrent violence?

This paper examines the divergence and convergence of the theory and practice of international criminal justice in order to provide a factual, textual and legal background that sketches out its redemptive sacrificial economy. Synthesising some common themes encountered in the subject area including global politics, exemplary trials, community-formation via exclusion and inclusion, secular and religious mystification, symbolism and perpetual promise, this paper's thesis is that international criminal law processes embody the international community through iconic presentation. The paper demonstrates this through a staged engagement between international criminal law and an innovative theoretical framework essentially sketching out an iconography of the criminal trial as being dependent upon a sacrificial economy. 


\section{The Universality and Promise of International Criminal Justice}

Arguably, universal justice has tensions within and between justice and universality. The opposition within justice regards simultaneously addressing individual criminal responsibility and mass violence that implicates a substantial segment of a population. The contradiction within universality is how a court set up by the international community with the potential to cover all States whether members of the Rome Statute or not only has African cases even after utilising all the various means by which it may be seized of jurisdiction. This is in the context of it only being able to act where the State that would otherwise do so is either unable or unwilling to perform its prosecutorial duty (Rome Statute 1998: Article 17).

\section{Community-Formation and Secular Mystification}

Sarah Nouwen and Wouter Werner have argued and demonstrated empirically that international criminal trials are an irreducibly political process (Nouwen and Werner 2010). Marti Koskenniemi says that the symbolism of the international criminal trial enables the formation of a moral community (Koskenniemi 2002). Koskenniemi says too that international law although secular has a horizon of transcendence couched in messianic language, whose present imperfections only sets off its yet fulfilled promises the brighter (Koskenniemi 2004: 507). Immi Tallgren points out that international criminal justice following the rhetoric of domestic criminal justice, sees all criminals (whether robbers or genocidaires), as having a single disease whose cure is deterrent punishment (Tallgren 2002). Given such rhetoric the logic of both domestic and international criminal justice is that achieving general prevention requires 'exemplary decisions' (Tallgren 2002: 576). This rhetoric and consequent logic are however inadequate to fully serve its expressive purpose being the prevention of criminality. (Tallgren 2002: 571-572). International criminal justice in this way attracts attention to itself and therefore away from what it is intended to address. International criminal law is consequently faith based. A 'kind of religious service of hope that is stronger than the desire to face everyday life' that enables the avoidance of the why question in international criminal law (Tallgren 2002: 593). To put it baldly, international criminal law enables global governance by simultaneously rationalising and mystifying political control (Tallgren 2002: 594-595). Gerry Simpson too demonstrates how international law seamlessly joins ostensibly extra-legal politics through the conferment of outlaw or pariah status, which takes piracy as the paradigm instance of extra-legalism (Simpson 2007:162). Pivotally for him individual international criminal responsibility began with pirates who were outside the international order and yet were the only natural persons directly subject to that legal order's control. As a matter of fact, both Empire and the international community need pirates as agents and objects of imperial ambition. Moreover, the category of 
'enemies of mankind' ensures the continued purchase of 'mankind' as a category capable of even waging perpetual war in the name of international justice (Simpson 2007: 177). On outlawry specifically, William Windeyer writing from the standpoint of Anglo-Saxon legal history on the origins of its domestic criminal law speculates that outlawry 'arose out of superstitious customs which led primitive men by taboos to rid the tribe of nefarious members' (Windeyer 1938:17).

Taking a cue from Koskenniemi, Nouwen, Werner, Simpson and one of their common interlocutors, Carl Schmitt who stated that all 'significant concepts of the modern theory of the state' are secularised theological concepts because of their 'historical development' and 'systematic structure' (Schmitt 2005: 36) I argue that the iconographic symbolism of a few representative trials at the Hague, an iconic city ('the legal capital of the world') to prevent mass organised political violence may be both irreducibly political and irreducibly theological. This argument demonstrates that unpacking the iconography of international criminal justice reveals that iconic trials in an iconic city by an iconic prosecutor have their own rhetoric, logic and aesthetic. The rhetoric is organised around achieving universal justice on behalf of the international community/humanity/mankind through singular trials of particular individuals. The logic follows a swopping of responsibilities between individuals and their communities via an uncertain and indirect substitution of personal rights for social harmony and order. The aesthetic presents and represents the ICC prosecutor as an image and icon of the international community's justice.

The logic, rhetoric and aesthetic all combine to provide an assemblage of means and methods for the ad hoc realisation of abstract principles i.e. an economy. This is specifically a sacrificial economy linking contingent means for realising permanent ends. All that is in order to visualise the invisible, and hear the inaudible international community through its icons as embodied representations of something that has its own existence yet which is only visible and audible through those icons (Mondzain 2005: 86). The icon sets up a relation between the visible and invisible without any respect for realism or neglect for the material (Mondzain 2005: 85). The question therefore is not whether the icon is by nature or by definition true or false, or even good or bad, because its truth is derived not from itself but from its founding cause (Mondzain 2005: 82). The essence of the iconic image is not its visibility (which belongs to imagery and not to iconicity); 'it is its economy, and that alone, that is visible in its iconicity'. (Mondzain 2005: 82). To belabour the point, the rhetorical, logical and aesthetical substitution of a flesh and blood prosecutor for the immaterial international community is precisely what visualises and renders audible that international community for the purposes of international criminal justice. The ethical position of this however falls short of what it aspires to. 
In theory, at least as per the rhetoric of the then UN Secretary-General Kofi Annan, the establishment of the ICC in 1998 was a historical moment gifting hope to future generations, and a great step towards universalising human rights and the rule of law (ICC 1998). Annan quoting Marcus Tullius Cicero's declaration that 'in the midst of arms, law stands mute': inter armes silent leges, said that there was now real hope that Cicero's cynicism would be less justifiable in the future than it had been in the past (ICC 1998). According to Annan until the moment establishing the ICC when powerful men committed crimes against humanity, they had known 'that as long as they remained powerful no earthly court could judge them'. Indeed even when they were judged here on earth (as happened in 1945) they could protest that it was merely a form of vengeance: 'victors' justice'. Consequently the accused could explain their guilt away by claiming their prosecution was really a persecution only occasioned by others who proved more powerful than they and those more powerful were in that way able to sit in judgement. At the same momentous occasion Philippe Kirsch, the chairman of the diplomatic conference setting up the court and later a president of the ICC concurred that setting up the court had established solid foundations of an institution, which would have a major impact for future generations. According to Kirsch, The international community had acted to show that it would not stand silently by as genocide was committed. The adoption of the Statute furthermore was 'really the future of humanity in many ways' (ICC 1998).

The occurrence of post-electoral violence in Kenya is a salutary case study referred back to repeatedly in this paper to illustrate different facets of the main argument as they develop. According to the ICC Prosecutor Luis Moreno-Ocampo, the leadership of Kofi Annan was essential for his office (ICC 2009e). A practical illustration of the working of the court pursuant to the theory of universal justice was when Annan in his capacity as chair of the African Union Panel of Eminent African Personalities, submitted to the ICC Prosecutor a sealed envelope containing a list of persons allegedly implicated in post-electoral violence occurring in Kenya (ICC 2009e). Annan explained that in Kenya there was no opposition between a truth commission and justice and suggested a three-pronged approach with the ICC prosecuting those most responsible, national accountability proceedings for other perpetrators as well as reforms and mechanisms such as the Truth, Justice and Reconciliation Commission (ICC 2009e).

Pursuant to this prompting from Annan the ICC Prosecutor subsequently said more than once that Kenya would be an example to the world/international community on managing and preventing recurrent political violence (ICC 2009c, ICC 2009d):

The Prosecutor emphasized that Kenya would prove an example of how to work together with the international community and the Court to end impunity and prevent future crimes. 'Kenya will show 
how to manage past violence and how to create a peaceful process for the upcoming elections in 2012. Kenya will be an example to the world.' ... 'We all agree that impunity is not an option,' he stressed, 'and that to prevent new violence in 2012 it is necessary to prosecute those responsible for the crimes committed during the post election violence.' (ICC 2009c).

To be fair, it was the Kenyan government itself that originated the idea in the first place of using international criminal prosecutions to prevent the recurrence of political violence:

Regarding Kenya, I met on 3 July with a Government delegation from Kenya, led by Justice Minister Kilonzo. They informed me that, in order to prevent a recurrence of violence during the next election cycle, those most responsible for the previous post-election violence must be held accountable. They are committed to ending impunity, and committed themselves to refer the situation to the Court if efforts to conduct national proceedings fail. (ICC 2009e).

For one thing, preventative exemplification to prevent mass violence is problematic because the law only provides the court with jurisdiction over natural persons who are to be individually responsible and liable for punishment without allowing corporate or group liability (Rome Statute 1998: Article 25). The selection of accused however does seem with a view to how they exemplify acts committed en masse and in concert. Indeed the prosecutor has assured that, the "persons bearing the greatest responsibility for the most serious crimes are being brought to justice' (ICC 2010b). What therefore does the ICC prosecutor mean when he constantly repeats the refrain that the Kenya situation would be an example supposedly to prevent recurring violence. Did the prosecutor speak literally or literarily? Is peace a cause or an effect of justice? A literal analysis of the trial process would only reveal an individual in jeopardy of his or her own life, liberty or property. This, bar a mysterious link, does not directly translate to communal peace. How does one prosecute their way to peace? Perhaps there is some indirect analogical relation amenable to elucidation.

A literary or figurative analysis by contrast to a literal one could link individual trials to communal peace, precisely through analogy by making an example of the accused to other potential accused. The point being that there is neither empirical proof nor factual analysis relied on or referred to linking peace and criminal trial only hopes, promises, suppositions, assumptions and central to this paper, ritualised conduct. Indeed interlocutors such as the prosecutor are not concerned with the actual reality of their intended results but only with their meaning in terms of iconicity to the various constituencies of international criminal justice. The Prosecutor and the Kenyans therefore speak of more than merely law and to understand those statements better we 
need to rely on more than a purely legal analysis of the pacifying preventative exemplar being brought to bear.

The example as a category is used for reasoning analogically by comparing a particular case to a particular case as opposed to either deduction - comparing from the universal to the particular or induction - comparing from the particular to the universal (Agamben 2009:19). The example is a curious case because while at the same time it belongs to and defines a category it does so simultaneously as part of and yet outside the same category it defines and belongs to (Agamben 1998:22 and Agamben 2009:24). Because there is no such thing as absolute guilt, insofar as an accused is made an example of by being tried and punished for the future possible actions of others he or she cannot help but be innocent. Yet at the same time he or she is guilty for his or her own past conduct making him or her simultaneously belong and not belong wholly to both the categories of innocence and guilt. That innocence although perhaps miniscule in the scheme of things is nevertheless critical. According to René Girard, innocence is esssential in creating a social scapegoat in order to prevent recurrent violence because it renders the sacrificial ritual different from vengeance and in that way arrests any spiral into endless mutually destructive violence through for instance vendettas without end (Girard 1977:14 and 22-26).

\section{Selective Universality}

The rhetoric is therefore that humanity sits in judgment over inhumanity. Given the geographic selectivity of the cases though, it would rather more accurately be put as one segment of humanity sits in judgment over another. One cannot help but detect a note of amphiboly here where Africans are exclusively responsible for all of humanity's very worst problems. Such indiscriminating use of universal sets in international criminal law not just humanity, but its synonyms, the international community, the world and mankind is under critiqued within the discipline. That lack of sufficient critique is probably because those sets are precisely what make the field itself intelligible and one cannot very well question them and remain comfortably meaningful within the field. These sets moreover are crucial and deployed at strategic moments in discourse.

They are crucial in providing a basis for both galvanising action and paralysing dissent and they are strategic in how they artfully structure the field into insiders and outsiders while at the same time claiming to act on behalf of both. Moreover, this acting on the behalf of both involves self-selected active insiders acting against more or less passively acquiescent outsiders. The outsider in terms of humanity nonetheless remains human and part of humanity. This stands to reason because non-humans could never be guilty of inhumanity. These sets of sets therefore paradoxically 
include and exclude at the same time insiders and outsiders. The insiders are included as actors but excluded as the acted upon while the outsiders are excluded as actors but included as the acted upon. Humanity therefore is the set of sets that simultaneously includes and excludes itself. That exclusive-inclusion and inclusive-exclusion dynamic is what makes the international system actually work in the first place and without it the system is again unintelligible and paralysed. Universality is arguably at present a useful legal fiction that on occasion cloaks injustice. Suppose we for a moment entertain the somewhat unusual thought (elaborated below) that a secular sacrificial economy lies at the root of international criminal justice, what would it mean if as according to Edward Carr this ethical system were built on the sacrifice of the weaker brother? (Carr and Cox 2001: 49, Koskenniemi 2005: 499).

Africa is the example par excellence of the outside and Africans are the perennial outsiders. However following from the argument outlined above, Africa and Africans constitute the international community's boundary as such via international criminal justice. In an empirical sense, Africans are the only ones currently under active investigation and trial at the ICC. This is not because of any deliberate intention of the prosecutor or any vast racial plot but follows through from the structure of a faith based and piety dependent criminal justice system where judges are not judged and trials are not tried. The reason why Africa is and shall remain the focus of international criminal law is that the boundary of the set of sets that is and contains humanity is perpetually under developed and in the interim requires to be conjured up through configuring beings that are simultaneously outside and inside by insiders that are at the same time inside and outside. The beings tried are broadly familiar as sacrificial scapegoats while those doing the trying are familiar as unaccountable sovereigns. A very specific form of scapegoating is done in international criminal law. The accused are supposed to bear the highest responsibility for the worst crimes known to humanity. The selection of Africans exclusively for this dubious honour while not random is definitely arbitrary. It is not random because there are real prima facie grounds indicating that persons from the region selected are responsible in some way for the commission of absolutely heinous acts (although as a legal technicality we must not assume this as those allegations are yet to be proven to the satisfaction of a court of law). It is arbitrary however because out of a total human population in the billions the few Africans selected neither have the monopoly on international criminality (not even in Africa) nor can they be the only ones of the very worst offenders.

A completely reasonable counter argument however could be made that Africa not only has the worst crimes but most significantly, also has the least infrastructure to deal with these crimes. So is Africa and are Africans the sole focus of international criminal law because of culpability or 
weakness or some admixture of both? Article 13 of the Rome Statute provides the trigger mechanism for the ICC's jurisdiction. This article codifies three separate modes for exercising jurisdiction. The first is the traditional basis of the consent of States. The second is through a referral of the United Nations Security Council by a resolution (UN Charter 1945: Chapter VII). The third provides for an independent prosecutorial power to refer a case. The first and the third are directly derived from State consent and also flow from specific articles of the Rome Statute, 14 and 15 respectively. Plainly because all the modes of triggering jurisdiction have been exhausted exclusively in relation to Africa, it is both culpability and weakness. That is precisely why the selection while arbitrary is not random. The inability to prosecute implies weakness but being unwilling to do so constitutes culpability. It would appear then that the pious hope by which punishment will surely follow crime is not perfectly congruent with this reality. Why is it that Africans appear to have the monopoly on the worst crimes humanity has to offer along with the weakest infrastructure to deal with them? Coincidence? Or is this structural weakness precisely why Africa is targeted and not any others.

Another objection raised could be that the case often celebrated as heralding the birth or beginning of international criminal law, that of Peter von Hagenbach is after all, neither from Africa nor of an African (Schabas 2007:1). Likewise, the trials after the Second World War of the Nazis, the Imperial Japanese and their Axis partners were also nothing to do with Africa. Even more so Italy, which could have provided some accused criminals for their wartime actions in Ethiopia, was not part of these post-war trial processes (Pankhurst 1999). However precisely those exceptional and therefore oft cited cases make the point that now international criminal justice has been normalised by setting up a permanent court the usual suspects are exclusively African and as yet not even exceptionally non-African. However given the glacially developing trend whereby the exception gradually becomes the rule (Benjamin 1996:392) Africans are only the vanguard for a globalising international criminal justice. Indeed Giorgio Agamben finds it unsurprising that there is a predilection to resort to exemplary punishment in a state of exception' (Agamben 1998:23). The Prosecutor himself said that the 'court is really helping to establish a new idea in the world with state parties and non-state parties. It will take time. In 30 years, all the world will be a member of the court but in the meantime we are progressing' (Menya and Reuters 2009). The court thus starts with Africans in order to cut its teeth before promising to sink its talons on bigger prey.

This is the point made again and again that a court yet to gain credibility and respect begins with going after the weakest and not necessarily the most criminal. Therefore it targets Africans not because they are the worst but because they are the weakest. This is supposed to somehow redeem 
the whole of humanity thus making Africa the perpetually scapegoated pharmakos given up and giving itself up to sacrifice in order to embody the international community through criminal justice. This is neither the time nor the space within which a comprehensive and satisfactory explanation of such a complex and longstanding social phenomenon as the scapegoat mechanism can be elucidated. However, various writers from both inside and outside the traditional international criminal law canon may enrich the discussion and shed some light on the particular concerns raised.

The characterisation 'universal justice' has the international community performing a seemingly external sacrifice. This is because the accused is taken out of the normal communal relations as a rogue, terrorist, pirate, outlaw, etc. (Simpson 2004:xi) On the other hand, the accused's community, which is also the 'accused community', provides an internal scapegoat to redeem itself. Socially unsanctioned violence violates that most sacred value (sanctity of human life), which requires a sacrifice (trial and sentencing of criminals) that produces a scapegoat (Noll 2008: 563, Girard 1986) through the punishment of individuals as responsible for future collective breaches of the peace by others. Such ambivalent figures are conceptually similar to persons declared anathema (Gignac 1907, Hubert and Mauss 1964, Agamben 1998, Simpson 2004:325). The sacrificial economy particularly clarifies inclusion and exclusion mechanisms in the construction and reconstruction of the relationship between the particular - a specific set of facts and the universal the general system of law (Fox 2007:563).

Agamben is one thinker whose philosophical musings provide particularly rich pickings for law generally and international criminal law in particular. His work on sovereignty and human life uncovers the economy of power and elucidates the actual and concrete workings of government through a close and minute examination of the ideal and abstract principles that are claimed to legitimate government and the governors (Agamben 1991:105, Agamben 2011:227, Zartaloudis 2010). With reference to exclusion and inclusion, the relative political value of lives and the increasingly globalised structure of both, he proposes three core theses that:

1. The original political relation is the 'ban' (the state of exception as a zone of indistinction between outside and inside, exclusion and inclusion).

2. The fundamental activity of sovereign power is the production of bare life as an originary political element and as threshold of articulation between nature and culture, zoë and bios. 3. Today it is not the city but rather the camp that is the fundamental bio-political paradigm of the west. (Agamben 1998:181) 
Ronjon Datta faults Agamben however for failing to show how the grotesque being relied on by Agamben that is reduced to so-called bare life or the homo sacer, that therefore cannot be sacrificed and so whose killing is not homicide, can in turn be rendered sacrifice-able (Datta 2009). One way that this can be done is of course via the scapegoat mechanism, which is simultaneously inside and outside. Religion is based on a sharp distinction between the sacred encompassing God, gods, mythical ancestors, etc. and the profane (Eliade 1996:1). In mythology, the sacred appears in the form of ideal models such as the actions and commandments of gods, heroes, etc. By manifesting itself as the ideal model, the sacred gives the world value, direction, and purpose (Eliade 1959:21). According to Emile Durkheim, 'religion is a unified system of beliefs and practices relative to sacred things, that is to say, things set apart and forbidden' (Durkheim and Fields 1995:47). James George Frazer believed sacer or taboo meant both sacred or profane (Frazer and Fraser 2009: xlix). According to Sigmund Freud sacer means sacred, blessed but also accursed and worthy of disgust (Freud and Jones 1939:156). Agamben and at least two of his sources Marcel Mauss and Henri Hubert note the double nature of sacer or sacred meaning both blessed and cursed making it pliable and open to anything (Hubert and Mauss 1964:3, Agamben 1998:184-185). This according to Agamben is secretly the potential status of all political beings from the sovereign to the musselman (the concentration camp inmate inured to all suffering and therefore unresponsive to external stimuli) when law makes life its object. It is thus feasible to manipulate gradations of belonging (and therefore of not belonging) to the point that the homo sacer being founds a criminal to be punished, or a soldier to be sent to their possible death, etc. So it is possible to relate how homo sacer can be rendered a sacrifice merely by tracing the legal genealogies of any readily identifiable social scapegoats.

The dominant iconic representations of Africans in the global mass media include the starving child with ribs poking out of his emaciated body, the swaggering pirate, bullets hung off his shoulder while nonchalantly holding onto a rifle and the hyphenated child-soldier who not only has his ribs sticking out too like the starving child but holds the rifle and ammunition just as well as and in a similar attitude to the pirate. The child-soldier is therefore paradigmatic of a limit figure. The innocently starving child and the viciously criminal pirate merge in the child-soldier who can be held responsible as a war criminal, or shown compassion as yet another victim of the war, or both at the same time and by the same means (by reduced or commuted sentencing following an international criminal trial). In the child-soldier victim and victimizer cross over into each other and become indistinguishable thus representing a form of bare life that indeed can be easily sacrificed or just as easily not sacrificed. An actual instance of such a victim and perpetrator is Dominic Ongwen a former 
child soldier who at the age of ten was kidnapped into the Lord's Resistance Army (LRA) in Uganda and yet is currently indicted as a war criminal by the ICC (Baines 2009).

\section{Substitutive Logic}

The logic underpinning the rhetoric of universal justice through individual criminal responsibility is one where the responsibilities of the whole are substituted for those of a part. To refer once more to the Kenyan case in the prosecutor's words the 'whole international community is with the Kenyans, all Kenyans must come together and use the law and justice as a basis for their common future. The common goal is to ensure there is no repeat of violence in the 2012 elections' (ICC 2010e). This is intended to 'end impunity to prevent future crimes' (Menya and Reuters 2009). The prosecutor said that 'Kenya will provide a historic example on how one country chose to address and prevent massive crimes' furthermore 'Kenyans, including women, youth, tribal groups, judicial, political, and religious leaders have a role. This is their court' (Mwanzia 2011). As per the prosecutor's rhetoric the international community is the community of communities in that it contains all Kenyan communities and individuals.

The Prosecutor's own original contribution to the Kenyan situation was to add exemplification as the means by which to achieve such a preventative approach to violence. He then proceeded to extend its effective reach from Kenya and Kenyans to the wider international community by saying: 'Kenya could be an example of how to manage this type of conflict because Kenya had a problem but Kenya stopped the crimes in two months. Now they have to do more to prevent repetition and ensure the next election is an example' (Thomasson 2011). This preventative exemplification to ward off violence thus became a running theme covering not just a specific election in time and space (Kenya in 2012) but also fifteen other elections elsewhere and at different times moreover all of them in the future:

The best example is Kenya. Justice for the post-electoral violence in Kenya will ensure a peaceful election in 2012. Additionally, it will send a clear message for the 15 elections to come in the region: violence during electoral times cannot be a tool to retain or to gain power; but it is a sure avenue towards a one-way ticket for prison in The Hague. That is the message we need to send in Kampala. (ICC 2010d)

Thus futurity is linked to collective liability to scapegoat the accused by apportioning responsibility for what has not yet occurred and is by no means certain to occur apparently on ultimate behalf of all of humanity. It was as though this is a liturgical exercise that has the prosecutor effectively 
intoning: 'here judged today is the individual responsible for the communal violence you have suffered (and perpetrated) whom is now punished. Peace be with you for now and ever more'. The recipients of this message of the trial as a spectacle shall, it is hoped respond affirmatively: 'there, but for toeing the peaceful line, go I'. And violence shall be no more peace would surely follow. Once again: '[t]he results of our investigations in the Kenya situation will be presented to the Judges in December. We are preparing two cases against six individuals. These cases could have a critical role to play in preventing violence in the next election in Kenya and in another fifteen countries of the region' (ICC 2010g).

This exemplary preventative approach is to be achieved by only trying those accused with the greatest responsibility for the worst crimes (ICC 2009):

The investigation will focus on those most responsible for the most serious incidents. We will try to conduct an expeditious investigation, aiming to present a sample representative of the crimes committed. We envision at least two cases against one to three persons in each case. We will focus on those who, according to the evidence that will be collected in the course of our independent investigation, are most responsible (ICC 2010c).

When examining relevant national proceedings of potential cases prosecutorial policy seems to follow the same line of holding a few individuals responsible for the mass by focussing on those who appear to bear the greatest responsibility for the most serious crimes (ICC 2010f). This approach is applied in enabling the selection of cases based on 'persons most responsible' or 'those bearing the greatest responsibility' but not making those standards legal preconditions for admissibility, which would be a hindrance to the prosecutor (ICC 2011a). The Assembly of State Parties to the ICC appears to endorse the view that the ICC has had to take a policy decision to focus prosecutions on 'those bearing the greatest responsibility for the most serious crimes' even though it is not prescribed in the Statute (ICC 2006). However, among professional criminologists there seems to be a broad consensus that the efficacy of punishment in acting as a general deterrent is not the most important factor in lowering crime rates (Bernard et al 2010:20-24). Moreover international criminal trials do little to deter violence or promote reconciliation (Snyder and Vinjamuri 2003-2004, Shaw, Waldorf, and Hazan. 2010: 31-32, Justice Report 2011).

\section{Images and Icons of the International Community}

Tallgren proposes that perhaps the purpose of international criminal law is less the prevention or suppression of criminality than the establishment of symbols, which enable belief in a 
legitimate international community that can be governed analogously to the nation-state (Tallgren 2002: 594-595). Tallgren suggests one way to focus differently on international criminal justice is as a continuous remembrance service, akin to divine religious services, which meaningfully targets the questions of life and death, good and evil, as well as the promises of justice, peace and love (Tallgren 2002: 593). Girard and Agamben have outlined the sacrificial and juridical logics inherent in such an exercise (Jenkins 2004). Lior Barshack for one conceives of the court as a social mechanism providing the centre of contemporary civil religion (Barshack 2000). Both Girard and Gregor Noll have noted before the proximities of sacrifice to violence and of the trial to the sacrifice (Girard 1977, Noll 2008). Secularisation is inadequate as a remedy because it is the shifting (rather than abolition) of concepts from one sphere (religion) to another (e.g. politics or law), consistently with their erstwhile function (Agamben 2009:77). Secularisation can therefore mean the obscured continuation of practices of religious origin more or less unrecognised or unacknowledged (Löwith 1949, Kantorowicz 1997, Schmitt 2005, Schmitt 2008, Gillespie 2008). Presently therefore sacrifice as a social function has shifted register in moving into law through politics from theology.

Aesthetics is central to law generally but international law in particular because such central features structuring it e.g. the aforementioned humanity but also sovereignty, the rule of law, human rights, etc. can only be interacted with indirectly in terms of their positive (actual performance) or negative (perceived lack) manifestation. This means that all of its main principles and concepts are always represented but never present in the real sense. That is to say they are not to be found as themselves within the material physical realm open to the senses except in and by representation. This is because - it is believed - they are to be found either above or perhaps below but in any event beyond the directly perceptible. Yet they remain in some normative sense the 'truth' behind the representative 'façade'. This briefly passes for the aesthetics of law. The argument indicates that any efforts directed towards interacting with these necessarily transcendent concepts could only be grounded in a secular sacrificial economy (Goodrich 1990:59, Zartaloudis 2010:16). That is to say if trial works by displacing social and individual perceptions of guilt onto the accused (who is selected for his or her sins but not only for his or her sins is he or she punished but also those of others) then it displays an irrepressible sacrificial economy.

The unfinished task of the Enlightenment however is demystification of society: to review social practices rationally and progressively for the traces they still bear of their originally religious mystifications (Girard, Oughourlian, Lefort 1987). In the meantime, though these mystifying conceptions march on and the interim task can only be to align them more closely with the stated objective of law, which is justice. For whatever it is worth, the efficacy of legal ritual in binding up 
violence is directly related to it using and obscuring these mystifying justifications. On the one hand, Enlightenment rationalism is the ideal yet to be fully realised; on the other, the unreflective use of the trial to bring about peace is credited as being and continuing to be effective in preventing violence. One thinly veiled truth of a secular society is that it operates as if it were still religious. This puts any open-minded observer in the somewhat confused and confusing position of a laudatory critic. Highlighting the redemptive peace-building capacities of the trial while exposing the underlying irrationality and consequent injustice underpinning its process.

\section{Social Catharsis}

Richard Dawkin's notion of memetic transmission encapsulates nicely the cultural shifting of the trial-as-sacrifice by explaining how the descent (if not the origin) of law and the legal system from the sacred could occur (Dawkins 2006:192). The trial can be seen in the form of a morality tale rippling across space and time through a series of memes; peace is good and beneficial while war is bad and attended with prohibitive cost. The trial is subsequently installed as an archive and repository of communal values. By linking prosecution of accused to achieving peace the prosecutor makes the virtual sacrifice paradigmatic of the international criminal trial and is thereby the central figure in drawing a particular historical narrative. The trial-as-sacrifice through the scapegoated pharmakos provides both social bonding and the binding of violence. This is how international criminal trials build the international community up through instrumentalising empathy or identifying the self with the other in the dock, which enables formation of society via outlawry, etc. where the excluded provides the boundary for inclusion Simpson 2004:xi).

To summarise the line of argument pursued to this point, the two limbs of the central ethical problem identified, the ambivalence of justice (by making an example of one from the past to others in the future) and ambiguity of universality (exclusive focus on Africa) are linked by the pharmakos mechanism through preventative approaches to legal justice. In the Kenyan case study chosen both the Kenyans and the Prosecutor share a common faith in the value of this preventatively sacrificial economy in hopefully eradicating violence. If the Kenyans initiated the process, then the ICC Prosecutor continued and extended it. Even so as we shall see below defence counsel note it with alarm and likewise the Prosecutor actually charges some accused with practising it themselves. Therefore in international criminal justice as social catharsis, the international community is making the sacrifice, Africans who both belong to and are excluded from the international community are the sacrifice and the entity they are sacrificed to is a 'justice' that is never present but is only ever represented. 
The paradox of individual criminal responsibility for mass communal violence has had defence counsel go on record with misgivings to this approach on the basis that it is liable to generate scapegoats:

When it comes to crimes in Ituri, those who are the most powerful are spared. Thomas Lubanga is charged in place of those who should have been prosecuted, and so the accused is placed in an unacceptable situation. The International Criminal Court is put before an immense danger, a fearsome danger, because the International Criminal Court cannot prosecute all of the suspects. And because it can never prosecute all of the suspects, international criminal justice must necessarily face the temptation to convict by proxy those who are absent. The danger is tremendous, because beyond the prosecution of an individual, an attempt is made to prosecute a criminal phenomenon which is far greater than him. The accused then becomes or risks becoming a scapegoat (ICC 2009b:31).

The defence counsel further expanded upon the idea portraying the accused as a scapegoat:

As regards scapegoats, we must ensure that the concept of individual criminal responsibility is applied. Only this vigilance on the principles and on the evidence can enable the International Criminal Court to meet the challenges of justice, the human and symbolic challenges inherent in any trial before it; and that double vigilance is all the more important, your Honours, in that in bringing before you to be judged Thomas Lubanga, and bringing before you Thomas Lubanga to be judged in the place of those who bear the greatest responsibility for the crimes committed in Ituri, one is seeking to have you play a role which is not yours, one which cannot be yours, one which must not be yours (ICC 2009b:33).

The spectre of the scapegoat also crops up in yet another case on this occasion introduced by the prosecution this time explicitly linked to the notion of sacrifice and as evidence to prove knowledge of serious crimes against a civilian population by the accused:

Witness 45 provides further details in regard to the trials. He states that none of the soldiers served a full prison sentence. The witness further states that Jean-Pierre Bemba reassured the ones tried that, and I quote: "It was done for outside people, and after that they would be released." ...

Approximately one month following their convictions, Jean-Pierre Bemba granted them amnesty and they were reintegrated into the MLC force. In referring to the case of Commander Ngalimo, who was the MLC commander, your Honours, in the Mambasa sector, the witness states that he was found guilty for the murders -- for murders and pillaging and sentenced to five years' imprisonment. And he further states that when Ngalimo complained of having been sacrificed and being used as a scapegoat, Jean-Pierre Bemba sent someone to reassure and promise him that he 
would be released soon thereafter. Only one month later, Ngalimo was granted amnesty and received a promotion to the rank of a colonel (ICC 2009a: 106).

In keeping with the perception of a redemptive sacrificial economy a former Kenyan Member of Parliament Ms Jayne Kihara of whom it is alleged that she financed and bought machetes for gangs involved in attacks chimed into the debate and referred to herself as a 'sacrificial lamb' (Gekara 2009). Sacrifice therefore meaningfully links even primarily oral and primarily literary communities. The example appearing in such different guises as precedent, or case study acts as a morality tale linking literal and figurative statements. It is therefore clear that potential accused, the prosecutor and defence counsel are all alive to the potential and dangers of using legal processes to generate scapegoats in a sacrificial context. To summarise the workings of the iconography envisaged, politically motivated violence in Kenya although unique once dealt with serves as an exemplary case to influence in future the international community generally and at least fifteen other African countries in particular. This renders any convicted individuals responsible not only for their own past actions, but also for the potential actions of others in the future. On the face of it, this is a departure from the norm because past rules guiding present actions provide the usual basis for the criminal law in which each person is individually responsible for wrongs already committed by them and not for the wrongs of others that are yet to be committed and indeed may never be committed.

The afflicted (and afflicting) communities are a singled out part of the international community and therefore the scapegoat is simultaneously from both local and global communities this is why the useful paradox of sacrality/homo sacer/scapegoat is relevant to explain how a being can be inside and outside at the same time. According to Jacques Derrida, the scapegoat or pharmakos is a being that simultaneously belongs and does not belong to society (Derrida 1981:130134). This coincidence between outsider and insider makes the scapegoat more easily amenable to sacrifice for communal atonement or expiation. They belong to the community enough to be associated with it but are just vulnerable enough within it to be picked on as the victims of sacrifice. The pharmakos therefore exemplifies a vehicle through which a social body figuratively expels evil, harm or wrongdoing from itself as a purificatory process. The scapegoat is paradoxical because it is the border between inside and outside making it both and neither.In this way society consitutes and reconstitutes both its make up and its moral values.

Frazer in his magisterial ethnographic study of the scapegoat meticulously documents examples from all over the world demonstrating the theory and practice behind how to ritually 
transfer the guilt of a whole people to an individual human, animal or object (Frazer and Fraser 2009:557). Indeed if we think of the human as a hyphen that connects god to animal, the dividing line between the two necessarily passes through the human that is a sort of divine animal (Derrida, Bennington 2009:13, Agamben 2004:37). According to Frazer 'when a nation becomes civilized, if it does not drop human sacrifices altogether, it at least selects as victims only such wretches as would be put to death at any rate. Thus the killing of a god may be confounded with the execution of a criminal'(Frazer and Fraser 2009:588-589). Further: 'a common and successful device is to consummate the sacrifice on the person of a malefactor, whose death at the altar or elsewhere is little likely to excite pity or indignation, since it partakes of the character of a punishment, and people recognize that if the miscreant had not been dealt with by the priest, it would have been needful in the public interest to hand him over to the executioner' (Frazer and Fraser 2009:660).

The ambivalence and ambiguity outlined make it possible to draw both distinctions (within universality and humanity) and comparisons (between separate cases both actual and potential) where there otherwise were none. Describing the exemplification process is therefore a foray into representations in the realm of law i.e. legal aestheticisation (Simons 2008:227). In being a cautionary example to others, the accused is a peace sacrifice in a literary, or figurative, or iconographic sense. This 'sacrifice for peace' element gives the entire international criminal trial a decidedly quasi-religious aspect with the trial standing in as a secular sacrifice that casts the accused as a social scapegoat for the preservation of peace. There are at least two challenges of representation here. One might be how to ground the real and immediate jurisdiction of the prosecutor over perpetually potential cases. The other is attendant upon portraying Africa as a terrain of and Africans as a cipher for all the worst of humanity's ills. The mysterious link between the two is the scapegoat/pharmakos mechanism already in several instances encountered above and further unravelled below.

\section{What is a Sacrifice? Core and Collateral Effects and Affects}

What would happen if a would-be sacrificial victim were given a voice? There are three examples of human sacrifice documented in the Christian Bible. To start with probably the least known, that of Jephthah of his daughter (we are not even told her name), she was sacrificed in exchange for victory in war over the Ammonites by her father. Apparently, although unhappy she accepted her fate quietly and was duly sacrificed (Carroll and Prickett 2008:310-312). The case of Abraham and his first-born son Isaac is probably more familiar than the first. Abraham was instructed to sacrifice Isaac to prove his piety towards God. While on the way to the altar when the 
unsuspecting son innocently inquired as to the whereabouts of the sacrificial lamb, he received the response that God would provide. Indeed God did but only after Abraham was about to slit his own son's throat as an offering (Carroll and Prickett 2008:23-24). We therefore are not informed as to what view Isaac would have had of the proceedings had he been fully appraised of them beforehand. The last example is probably the most well known and influential where Jesus Christ the half-god half-man was given over in sacrifice by God his father to humanity in order to redeem that humanity (Carroll and Prickett 2008:39). Jesus, while fully aware of and initially willing to go along with the sacrificial elements of his death, nevertheless expressed some reluctance subsequently overcome to accept it (Carroll and Prickett 2008:41). More to the point the last is a profoundly influential sacrifice because its daily ritual re-enactment and reaffirmation does not require an actual death but only simulates the original foundational sacrifice of Christ's crucifixion. One does not have to be a Christian believer to appreciate the value of a simulated death underpinning such a nevertheless efficacious sacrifice.

A sacrifice is therefore not a simple word at all. It requires at a bare minimum three elements, the person, animal or object offered up for sacrifice itself, the individual or community making the sacrifice and the immaterial but representable idea, being or deity being sacrificed to (Hubert and Mauss 1964). The relationship between these various elements is an additional layer of complexity. The sacrifice and the person making the sacrifice must be somehow connected without necessarily being identical. The relationship between the person making the sacrifice and the entity to which the sacrifice is addressed can only be representative. That is, both indirect and uncertain. This interaction is therefore not one of direct exchange or a trading of favours as it were but more one of supplication, which if performed in the ritually correct manner promises to bring about the desired response.

Sacrifice is a transcendental concept, which as such is a necessary condition of possibility for the international criminal justice system. As seen above the phenomenon of redemptive sacrifice is not new or even new in its theological aspects to international law (Beard 2003, Beard 2006, Grbich 2006, Orford 2006). The elements of sacrifice most relevant to international criminal justice are redemption, atonement, expiation and purification. Redemption connotes deliverance from sin and damnation including by atonement or expiation. Expiation is a means by which redress (for a crime or offence) is made by an accused through for instance punishment. Atonement connotes restoration or reconciliation of friendly relations by reparation of wrong or injury through making amends or providing satisfaction and in that way purifies society off the pollution of the harm done. 
By empathising with sacrificial victims it is imperative to note that a sacrifice by its very nature is just a performative exercise that it is never literally true but only either efficaciously or inefficaciously performed. There can never be any real sacrifices because it is all about figuratively indirect and therefore necessarily uncertain substitutions. They are all simulations, ritualised exercises to bind society through compelling spectacle. As a virtual activity, therefore they do not need the collateral real and repetitive spilling of blood as it were to impress their core moral or political lessons upon pious or impious onlookers. The affective states that trials are intended to produce on the audience are not directly linked to their punitive effects on the accused.

Although sacrifice links simultaneously both violence and trial in international criminal justice nothing has as yet been written on it as being explanatory of Africa's peculiar position within it. This paper exposed the sacrificial economy of law not merely to note or even applaud its potentials and redemptive capacity, but it is also a directed critique suggesting that international criminal justice is all and only about affects and icons. That such a sacrificial economy of law could potentially be organised without any actual victims. One possible way towards this is to shift emphasis from law enforcement aimed at redressing breaches once they occur to law fulfilment addressed at achieving the promise of the law before it is breached (Agamben 1991, Agamben 2011:). All we should unflinchingly acknowledge the anarchic core of international justice where violence is both benediction and malediction simultaneously. Consequently short-term interventionist and in the end ineffectual responses to political violence should be abandoned. The study begun by attempting a partial demystification of basic concepts in the panoply of international criminal justice not in order to advocate abolishing or abandoning them immediately but to suggest finally positive ethical transformations in their use in order to align those practices more closely to the aims of apportioning responsibility equitably, promoting reconciliation in affected communities, and encouraging remorse in convicted offenders in order to prevent the recurrence of political violence. This would hopefully bind the sacrificial logic, rhetoric and aesthetic of international criminal justice to an ethic of empathy that strives to be truly universal and truly just.

\section{Acknowledgments}

I acknowledge gratefully the helpfully critical comments on earlier drafts of this article by Peter Rush, Philip Stenning, Wouter G. Werner, Immi Tallgren and the two anonymous reviewers.

\section{References}

Books

Agamben, Giorgio. 1991 Language and Death: The Place of Negativity. Minneapolis: University Of Minnesota Press. 
Agamben, Giorgio. 1998. Homo Sacer: Sovereign Power and Bare Life. Stanford: Stanford University Press.

Agamben, Giorgio. 2004. The Open: Man and Animal. Stanford: Stanford University Press.

Agamben, Giorgio. 2009. The Signature of all Things: On Method. New York, Cambridge, Mass.: Zone Books.

Agamben, Giorgio. 2011 The Kingdom and the Glory: For a Theological Genealogy of Economy and Government. Stanford: Stanford University Press.

Bernard, Thomas J., et al. 2010. Vold's theoretical criminology New York: Oxford University Press.

Carroll, Robert P., and Stephen Prickett. 2008. The Bible: Authorized King James Version, Oxford world's classics. Oxford ; New York: Oxford University Press.

Carr, Edward Hallett and Cox, Michael. 2001. The twenty years' crisis, 1919-1939: an introduction to the study of international relations Houndmills, Basingstoke, Hampshire ; New York: Palgrave

Dawkins, Richard. 2006. The selfish gene (30th anniversary ed,). New York: Oxford University Press.

Derrida, Jacques and Bennington, Geoffrey. 2009. The beast and the sovereign, Seminars of Jacques Derrida Chicago: The University of Chicago Press.

Derrida, Jacques. 1981. Dissemination. Chicago: University Press.

Eliade, Mircea. 1996. Patterns in comparative religion. Lincoln: University of Nebraska Press.

Eliade, Mircea. 1959. The sacred and the profane; the nature of religion. New York: Harcourt.

Durkheim, The Elementary Forms of the Religious Life, (1912, English translation by Joseph Swain: 1915) new translation by Karen E. Fields 1995 p. 47.

Frazer, James George and Fraser, Robert. 2009. The Golden Bough: A Study in Magic and Religion (Reissued edn., Oxford world's classics; Oxford ;: Oxford University Press)

Freud, Sigmund and Jones, Katherine. 1939. Moses and monotheism London: The Hogarth press and the Institute of Psycho-analysis.

Gillespie, Michael Allen. 2008. The theological origins of modernity. Chicago: University of Chicago Press.

Girard, René, 1977. Violence and the Sacred. Baltimore: Johns Hopkins University Press.

Girard, René. 1986. The scapegoat. Baltimore: Johns Hopkins University Press.

Girard, René, Oughourlian, Jean-Michel and Lefort, Guy. 1987. Things hidden since the foundation of the world Stanford, Calif.: Stanford University Press.

Goodrich, Peter. 1990. Languages of law : from logics of memory to nomadic masks, Law in context. London: Weidenfeld. 
Hubert, H. and M. Mauss. 1964. Sacrifice: its nature and function. Chicago, University of Chicago Press.

Kantorowicz, Ernst H. 1997. the King's Two Bodies: A Study in Mediaeval Political Theology. Princeton: Princeton University Press.

Koskenniemi, Marti. 1989. From Apology to Utopia: the Structure of International Legal Argument Helsinki: Finnish Lawyers Publishing Company.

Löwith, Karl. 1949. Meaning in history; the theological implications of the philosophy of history. [Chicago]: Univ. of Chicago Press.

Mondzain, Marie-José. Image, Icon, Economy: The Byzantine Origins of the Contemporary Imaginary, Cultural Memory in the Present. Stanford, Calif.: Stanford University Press, 2005.

Schmitt, Carl. 2005. Political theology: four chapters on the concept of sovereignty. University of Chicago Press ed. Chicago: University of Chicago Press.

Schmitt, Carl. 2008. Political Theology II: The Myth of Closure of any Political Theology. Cambridge: Polity Press.

Schabas, William. 2007. An introduction to the International Criminal Court. Cambridge, UK ; New York: Cambridge University Press.

Simpson, Gerry J. 2004. Great powers and outlaw states: unequal sovereigns in the international legal order, Cambridge studies in international and comparative law. Cambridge, UK ; New York, NY: Cambridge University Press.

Simpson, Gerry. 2007. Law, War \& Crime. Cambridge, UK: Polity Press.

Windeyer, William John Victor (1938), Lectures on legal history (Sydney etc.: Law Book Co. of Australasia Pty Ltd.) xv, 280 p.

Zartaloudis, Thanos. 2010. Giorgio Agamben: power, law and the uses of criticism, Nomikoi, critical legal thinkers

\section{Book chapters}

Benjamin, Walter, et al. (1996), Selected writings, 4 vols. (Cambridge, Mass.: Belknap Press) Volume 4.

Grbich, Judith 2006 'Secrets of the Fetish in International Law's Messianism' in Anne Orford (ed), International Law and its 'Others'. Cambridge ; New York: Cambridge University Press.

Orford, Anne. 2006. 'Trade, Human Rights and the Economy of Sacrifice' in Anne Orford (ed), International Law and Its Others Cambridge ; New York: Cambridge University Press.

Shaw, Rosalind, Lars Waldorf, and Pierre Hazan. 2010. Localizing transitional justice : interventions and priorities after mass violence, Stanford studies in human rights. Stanford, Calif.: Stanford University Press. 


\section{Journal articles}

Alber, John, Daniel C. O'Connell, and Sabine Kowal. 2002. Personal perspective in TV interviews. Pragmatics 12: 257-271.

Baines, Erin K. 2009. Complex political perpetrators: reflections on Dominic Ongwen. The Journal of Modern African Studies 47 (02): 163-191.

Barshack, Lior 2000 'The Totemic Authority of the Court' Law and Critique, Vol. 11: 301-328,

Beard, Jennifer 2003 'Understanding International Development Programs as a Modern Phenomenon of Early and Medieval Christian Theology' 18 Austl. Feminist L.J: 27-54.

Beard, Jennifer. 2006. 'The Confessional Framework of Rule of Law Development: How to Offer Salvation to Willing Legal Subjects'75 Nordic J. Int'I L. : 409 -449.

Datta, Ronjon Paul. 2009. 'From political emergencies and states of exception to exceptional states and emergent politics: a neo-Durkheimian alternative to Agamben', International Social Science Journal, 58: 169-82.

Fox, Christopher A. 2007. Sacrificial pasts and messianic futures: Religion as a political prospect in René Girard and Giorgio Agamben. Philosophy Social Criticism 33(5): 563-595.

Jenkins, Fiona 'Dialogue in the Aftermath: On good, evil and responsibility after September 11' $\begin{array}{lllll}\text { Volume } & 3 & \text { Number } & 1 & \text { 2004borderlands ejournal }\end{array}$ http://www.borderlands.net.au/vol3no1_2004/jenkins_dialogue.htm 9th October 2009.

Koskenniemi, Marti 'Between Impunity and Show Trials' Max Planck Yearbook of United Nations Law, Volume 6, Number 1, 2002, pp. 1-32.

Koskenniemi, Marti 2004 'International Law as Political Theology: How to Read Nomos der Erde?' Constellations Volume 11 No 4: 492-511.

Noll, Gregor. 2008. 'The Miracle of Generative Violence? René Girard and the Use of Force in International Law' Leiden Journal of International Law 21(03): 563-580.

Nouwen, Sarah and Werner, Wouter G. 2101. Doing Justice to the Political: The International Criminal Court in Uganda and Sudan The European Journal of International Law Vol. 21 no. 4: 941-96

Pankhurst, Richard. 1999. Italian Fascist War Crimes in Ethiopia: A History of Their Discussion, from the League of Nations to the United Nations (1936-1949). Northeast African Studies 6.1: 83-140. Project MUSE. Web. 21 Jan. 2011. <http://muse.jhu.edu/>.

Snyder, Jack L. and Vinjamuri, Leslie. 2003-2004. Trials and Errors: Principle and Pragmatism in Strategies of International Justice. International Security 28.3: 5-44. Project MUSE. Web. 2 Apr. 2011. $<$ http://muse.jhu.edu/> 28: 5-44.

Tallgren, Immi. 2002. The Sensibility and Sense of International Criminal' Law European Journal of International Law Issue Vol. 13 No. 3: 561-595. 
International Conventions

The United Nations. 1945. Charter of the United Nations, 1 UNTS XVI (entered into force 31August 1965).

The Rome Statute of the International Criminal Court. 1998. Opened for signature 17 July 1998, 2187 UNTS 3, (entered into force 1 July 2002).

Online documents

Gekara, Emeka-Mayaka 2009 'Former MP pleads innocence against war crimes' Daily Nation Newspaper http://www.nation.co.ke/News/politics/-/1064/817672/-/wu6ptcz/-/index.html. 4 December 2009. Accessed 11 April 2011.

'Gignac, J. 1907. Anathema. In The Catholic Encyclopedia. New York: Robert Appleton Company. Retrieved April 11, 2011 from New Advent: http://www.newadvent.org/cathen/01455e.htm Accessed 11 April 2011.

ICC. 1998. Press Release L/2890 Secretary-General Says Establishment of International Criminal Court Is Major Step In March Towards Universal Human Rights, Rule Of Law http://www.icccpi.int/NR/rdonlyres/01668F61-04C7-405C-BE43-CA3078E9DFAD/274176/41833.pdf. 20 July 1998. Accessed 11 April 2011.

ICC 2006. Session 2: NGOs and Other Experts The Hague, http://www.icccpi.int/menus/icc/structure\%20of\%20the\%20court/office\%20of\%20the\%20prosecutor/network\%20 with\%20partners/public\%20hearings/second\%20public\%20hearing/session\%202/session\%202?lan= en-GB. 26 September 2006. Accessed 11 April 2011.

ICC. 2009a. http://www.icc-cpi.int/iccdocs/doc/doc618933.pdf Confirmation of Charges Hearing (Open Session) Page 1 International Criminal Court Pre-Trial Chamber III Situation in the Central African Republic - case ICC-01/05-01/08 Confirmation of Charges Hearing - Open Session. 14 January 2009. Accessed 11 April 2011.

ICC. 2009b. International Criminal Court Trial Chamber I Situation in the Democratic Republic of Congo - Case ICC-01/04-01/06 Hearing - Open Session Tuesday, 27 January 2009 Case No. ICC-01/0401/06 Tuesday, ICC-01/04-01/06-T-109-ENG WT 27-01-2009 1/59 NB T http://www.icccpi.int/iccdocs/doc/doc623848.pdf. 27 January 2009. Accessed 11 April 2011.

ICC. 2009c. ICC Prosecutor: Kenya Can Be an Example to the World Press Release: ICC-OTP20090918-PR452 http://www.icccpi.int/menus/icc/structure\%20of\%20the\%20court/office\%20of\%20the\%20prosecutor/comm\%20an d\%20ref/kenya/pr452?lan=en-GB. 18 September 2009. Accessed 11 April 2011.

ICC. 2009d. ICC Prosecutor Supports Three-Pronged Approach to Justice in Kenya ICC Press Release: ICC-OTP-20090930-PR456 http://www.icccpi.int/menus/icc/situations\%20and\%20cases/situations/situation\%20icc\%200109/press\%20release s/pr456?lan=en-GB. 30 September 2009. Accessed 11 April 2011.

ICC. 2009e. Mr Luis Moreno-Ocampo Prosecutor of the International Criminal Court Seventeenth Diplomatic Briefing Statement http://www.icc-cpi.int/NR/rdonlyres/B2000A0D-2159-40E6-A24F- 
8952FF34D3B4/281196/OTP DiplomaticBriefing 04112009.pdf 4 November 2009. Accessed 11 April 2011.

ICC. 2010a. Part II Resolutions adopted by the Assembly of States Parties http://www.icccpi.int/iccdocs/asp docs/ASP8/OR/OR-ASPR8-ENG.PART.II.pdf. 25 March 2010. Accessed 11 April 2011.

ICC. 2010b. Resolution ICC-ASP/8/Res.9 Adopted at the 10th plenary meeting, on 25 March 2010, by consensus http://www.icc-cpi.int/iccdocs/asp docs/Resolutions/ICC-ASP-8-Res.9-ENG.pdf. 25 March 2010. Accessed 11 April 2011.

ICC. 2010c. Statement: OTP Press Conference on Kenya, Prosecutor Moreno-Ocampo's Statement, 1 April 2010 http://www.icc-

cpi.int/menus/icc/structure\%20of\%20the\%20court/office\%20of\%20the\%20prosecutor/reports\%20a nd\%20statements/statement/20100401?lan=en-GB . 1 April 2010. Accessed 11 April 2011.

ICC. 2010d. 18th Diplomatic Briefing 26 April 2010 ICC 2010 Luis Moreno-Ocampo Prosecutor of the International Criminal Court Statement The Hague, 26 April 2010. Accessed 11 April 2011.

http://www.icc-cpi.int/NR/rdonlyres/CA355D60-EC32-467A-8CA6F7FA93D86C0B/281862/100426LMOspeechdiplomaticbriefing final1.pdf. Accessed 11 April 2011.

ICC. 2010e. ICC 2010 Press Release: ICC Prosecutor to visit Kenya to meet victims and listen to all Kenyans ICC-OTP-20100504-PR521 http://www.icccpi.int/menus/icc/press\%20and\%20media/press\%20releases/press\%20releases\%20(2010)/icc\%20pr osecutor\%20to\%20visit\%20kenya\%20to\%20meet\%20victims\%20and\%20listen\%20to\%20all\%20keny ans?lan=en-GB 4 May 2010. Accessed 11 April 2011.

ICC. 2010f. Policy Paper on Preliminary Examinations DRAFT The Hague http://www.icccpi.int/NR/rdonlyres/E278F5A2-A4F9-43D7-83D2-

6A2C9CF5D7D7/282515/OTP Draftpolicypaperonpreliminaryexaminations04101.pdf. 4 October 2010. Accessed 11 April 2011.

ICC. 2010g. 19th Diplomatic Briefing Statement Mr Luis Moreno-Ocampo Prosecutor of the International Criminal Court http://www.icc-cpi.int/NR/rdonlyres/F67584DE-F045-45E2-95038F4D16B3DEAA/282656/LMO DiploBriefingspeech 03112011.pdf. 3 November 2010. Accessed 11 April 2011.

ICC. 2011a. The Appeals Chamber Situation In The Democratic Republic Of The Congo Situation In The Democratic Republic Of The Congo Public Redacted Version Prosecutor's Document in Support of the Appeal brought by the Prosecution against Pre- Trial Chamber I's 10 February 2006 Decision on the Prosecutor's Application for Warrants of Arrest, Article 58 http://www.icccpi.int/iccdocs/doc/doc1009321.pdf 28 January 2011. Accessed 11 April 2011.

ICC. 2011b. Widespread or systematic killings in Cote d'Ivoire may trigger OTP investigation http://www.icc-cpi.int/NR/exeres/85A578D5-946A-44C3-9908-1C2243062EF0.htm 6 April 2004. Accessed 11 April 2011. 
ICC. 2011c. Situations and cases http://www.icc-cpi.int/Menus/ICC/Situations+and+Cases/. 11 April 2011. Accessed 11 April 2011.

Justice Report. 2011. Trials Have Not Helped Reconciliation, Survey Shows. 11 April 2011. http://www.bim.ba/en/264/10/32161/ Accessed 11 April 2011.

Menya and Reuters. 2009. Ocampo urges Kenya unity over reforms http://www.nation.co.ke/News//1056/680212/-/item/1/-/100yn8fz/-/index.html 1 November 2009. Accessed 11 April 2011.

Mwanzia, Mutinda. 2010 Ocampo's action plans:

http://www.standardmedia.co.ke/InsidePage.php?id=2000006874\&catid=4\&a=1 1 April 2004.

Accessed 11 April 2011.

Thomasson, Emma. 2009. Darfur, Kenya courts to complement ICC: prosecutor

http://af.reuters.com/article/topNews/idAFJOE59TONA20091030. Accessed 11 April 2011.

UN 2011 The United Nations Security Council referred Libya by unanimous resolution http://www.un.org/News/Press/docs/2011/sc10187.doc.htm 26 February 2011. Accessed 11 April 2011. 